\title{
A Physiological Approch to Study of Concept of Ayurveda and Yoga in Management of Pain
}

\author{
${ }^{1}$ KaleVrushali , ${ }^{2}$ Marghade Nirmala \\ ${ }^{1,2}$ Department of Kriyasharir, Bhausaheb MulakAyurved Mahavidyalaya\& Hospital, Nandanwan, Nagpur.
}

\begin{abstract}
Pain is multidimensional, hence, there is very advanced researches on it in science nowadays, but pain still remains the major cause of disability affecting the large number of population in the world. An integrated approach towards Pain Management should possibly answer the grief involved in treating this Symptom of varying degrees. Beginning with, in this article, along with the classical text with special references to pain, and its management through ayurvedic procedures (Snehan, Swedan, Agnikarma, Jalaukaavcharan, Vedhankarma, Lepankarma\&Bastikarma) we have also focused on some other aspects to eliminate the chronic pain, such as removing toxins, proper nutrition, creating strong digestion, stress management etc. Further, concentrating on the physical body, Yoga eventually influences all aspects of the person: vital, mental, emotional, intellectual and spiritual. The asanas and pranayama harmonize the physiological system and initiate a 'relaxation response' in the neuroendocrinal system. Also we have thrown a light on, the role of Madhur-Amla- Lavan Rasa Aushadhiin Pain management due to DhatukshayjanyaVataprakopain view of G-PCR bio-signaling of taste and Pain modulation is incorporated to explain role of palliative medicines.
\end{abstract}

Keywords - Pain Management, Ayurved, Yoga, Palliative Treatment, Diet.

\section{INTRODUCTION}

- Pain is no longer a symptom; it lasts beyond natural healing periods accompanied by a sensitized nervous system disallowing natural checks and serves no useful purpose. There are several chemical, anatomical, patho-physiological and genetic alterations in the neural pathways that lead to persisting patterns of pain.[1],[2]

- The International Association for the Study of Pain defines pain as- 'An Unpleasant sensory and emotional experience arising from actual or potential tissue damage.[3]

- In Ayurvedic classical text SushrutSamhita we found terms such as Shool, Ruja, Vedana and Rukrevealing condition of Pain. Similarly, in CharakSamhitaAngmardprashaman(10 drugs used in treatment of Body ache), Shoolprashaman\&VednasthapakMahakashayais mentioned.[4],[5]

- This article elaborates various treatment modalities mentioned in Ayurveda in context to pain management such as Snehan(Oleation), Swedan(Fomentation), Agnikarma(Heat burn Therapy), Jalaukaavcharan(Leech therapy), Vedhankarma(needle puncturing), Lepa(medicated paste), Bastikarma (enema) is discussed.

- Yoga, as an interesting exercise modality, not only has been proved to have effects on physical building [6] but also could give the practitioner a union over their mind, body and spirit, [7], [8] which means yoga may have effects on mental health. This article is a systematic review intentioned to summarize the available evidences of effect of role of Ayurveda and yoga in the pain management. 
${ }^{1}$ KaleVrushali , International Journal of Ayurvedic \& Herbal Medicine 9(3) May.-June. 2019 (3546-3552)

\section{BASIC CONCEPTS OF AYURVEDA IN PAIN}

- In Ayurvedic texts, various terms such as, Ruk, Ruja, Vedana\&Shoolare commonly used for pain, however, 'Shool' is more appropriate term amongst all, stating the definition of Shoolas experience similar to driving a nail into the body of the person.[9]

- Further, it has been elaborated that out of Tridoshas, vitiated 'Vata' is the main causative factor responsible for all painful conditions.Pain is an indication of Vata imbalance [10]. This vitiation of Vataoccurs in two ways, viz. Dhatukshyajanya Vataprakopand Margavarodhjanya Vataprakop. [11] Similarly, 'Ruksha' and 'Chala' Gunas(characters) of Vataare mainly involved in the manifestation of pain.

- The aggravated Vata brings Rukshata (dryness), Lagutva (porousness) Kharatva (Courseness) which causes the symptom of pain. Classification of Pain as mentioned in Ayurveda, specifically discusses the types of Shoolimplying colic. As per SushrutSamhita, Shoolis classified into 13 types as per the location of visceral organs. As per Doshas, Shoolis classified into 16 types in Madhavnidan (8 types as per Doshas +8 types of Parinaamshoolas per Doshas), 8 types in Yogratnakar\& 4 types in KashyapSamhita.[12],[13],[14],[15].

- According toAyurveda, chronic pain is caused by doshik imbalances and is influenced by many factors like diet, digestion, toxin accumulation, stress, exercise and daily routine.

\section{AYURVEDIC TECHNIQUES FOR MANAGEMENT OF PAIN}

\section{Snehan Karma:}

Snehan(oleation) is dmentioned as Purvakarmaand practiced before all Panchkarmaprocedures. Due to Sneh(oleation) VataDoshagets pacified. BahyaSnehanor Abhyangais application of oil on the skin which is again divided into SarvangaSnehan(whole body massage) or SthanikSnehan(application of oil locally to the affected part like Janubasti, Katibastior Manyabastietc. As per the modern perspective, the Neuro-hormonal effects of BahyaSnehanhas been established, stating that massage increases levels of Dopamine, increases availability of serotonin, may elevate epinephrine (adrenaline) and release of endorphins. (Research conducted at TOUCH Research Institute at the University of Miami). All these neuro-hormones alter brain chemistry which in turn reduces response to pain sensation.[16]

\section{Swedan Karma:}

Swedan(hot fomentation) is also the Poorvakarmato Panchkarmawhich helps in inducing sweating to the patient. The role of Swedancan be explained with Transient Receptor Potential Channels which are mainly found in nociceptive neurons of peripheral nervous system. Role of Swedanin management of pain can be explained through TRPV1 channels which are responsible for perception of heat and pain. [17],[18].

\section{Agnikarma Therapy:}

Agnikarma(Heat burn Therapy) is one of the Para surgical procedures described for the pain management. Agnikarmahelps in relieving pain. In painful conditions especially musculoskeletal pain such as heel pain, Osteoarthritis, Frozen shoulder etc. Agnikarma, leads to pacification of Vata\&KaphaDosha, thereby reducing pain. Similarly, Agnikarmapacifies MandaDhatvagni and facilitates Amapachanand increases the Dhatvagni, thereby, metabolite toxins are removed. Thus, pain caused by the accumulation of metabolic waste products in the tissues is immediately relieved after AgnikarmaTherapy.[19]

\section{Raktamokshan by Jalauka:}

Jalaukaavcharan(Leech therapy) involves application of Jalauka(Leeches) for removal of vitiated blood at the site of pain.[20]It is proved by various researches that the sensory stimulus caused by the pain and burning sensation of the leech bite can alleviate the symptoms of the patient through the "gate theory". The main components of Medicinal Leech saliva is Hirudin which inhibits blood coagulation by binding to 
${ }^{1}$ KaleVrushali , International Journal of Ayurvedic \& Herbal Medicine 9(3) May.-June. 2019 (3546-3552)

thrombin, Bdelins acts as anti-inflammatory and inhibits trypsin, Eglins acts as anti-inflammatory and inhibit activity of cathepsin G, Carboxy-peptidase A inhibitors increases the inflow of blood at the bite site, Histamine like substance, acetylcholine acts as vasodilator and Anesthetic substance which causes anesthesia at the bite site.[21],[22]

\section{Viddhan karma:}

Vedhan karma is one of the eight Shastrakarma(surgical measures) mentioned in SushrutSamhita.[23]In Viddha karma the points are pierced with special hollow needles which leads to painful mechanical stimulus which causes release of endorphins thereby, causing immediate pain relief. Few Ayurveda experts are practicing a modified Agnikarmaprocedure named- Viddhagni, by clubbing Agnikarma\&Vedhan karma together. However, there is no validated document available to prove its supremacy over the conventional Agnikarma therapy.

\section{Lepanchikitsa:}

This is application of medicated paste over the painful body parts. Sushruta has described Lepanin Twakgatvata, MansagataVataand in management of pain due to Vranshopha.[24],[25].The mechanism of action of lepancan be explained with the Mechanism of transduction of cold thermoreceptors as for example Menthol sensation is perceived via TRPM8 channel; whereas role of Pradehacan be explained with TRPV1 channels and furthermore certain Warm receptors also being sensitive to painful stimuli function as nociceptors.[26],[27],[28].

\section{Bastichikitsa:}

In Bastikarmathe medicinal dravyasare administered into the rectum of the patient. Since, every Pain is attributed to vitiated VataDoshaand in order to correct this imbalance Bastiis the main (prim) treatment modality amongst the Panchkarmatherapies.[29] It is hypothesized that Basti karma has a feature to regulate sympathetic activity, thereby, balancing the autonomic nervous system. Hypothalamus- Pituitary-Adrenal axis (HPA) gets activated with the visceral afferent stimulation, involving the release of neurotransmitters from adrenal gland called cortisol, a neuroendocrine hormone, acts as a potent anti-inflammatory systemically.[30],[31],[32]

\section{Palliative Treatment (Shaman Chikitsa) in the Management of Pain}

The main objective of palliative treatment is to correct the vitiated VataDosha. Further, to resolve this Vataimbalance and pain Madhur, Amla\&Lavan Rasa (taste) herbs are prescribed.[33]

This concept can be better understood through the knowledge of receptors on cells that mediate Taste \& Pain both. G-Protein Coupled Receptors are dynamic machines for signaling Pain. [34] These same group of receptors (T1R2 \& T1R3 receptors) are responsible for perception of Sweet taste (Madhur Rasa) thereby, making us understand the role of Madhur Rasa in resolution of pain. As regards, Lavan(Salty taste - ENaC Receptors) \&Amla(Sour taste - Two TRP channels - PKD2L1, which are also present in pain fibers responding to chemical stimuli like Capsaicin \& menthol) use ion channels-proteins that form a channel through which specific inorganic ions can diffuse. Changes in cellular ion concentrations could then be detected and transmitted to the nervous system. However, Dr. Charles Zuker, meanwhile, states that current ion channel theory is not correct and GPCRs could also be involved in these perception modalities. In a nutshell, the role of GPCR in mediation of pain and mediation of taste thereby, explaining the role of Madhur, Amlaand Lavan Rasa in the Pain management.[32],[34],[35],[36]

\section{Diet and Proper Nutrition}

Ayurveda advices nutrition is the key to tackling pain symptons. A satvic diet pacifying to both Vata and Pitta doshas is recommended. For genral pain-killing ginger herbal tea, mahanarayan oil, turmeric and 
${ }^{1}$ KaleVrushali , International Journal of Ayurvedic \& Herbal Medicine 9(3) May.-June. 2019 (3546-3552)

Cayenne Pepper are very good. Ayurveda advices an easy to digest and satisfying and nourshing dietary approach that improves the digestion along with ayurvedic herbal formulas, which helps in restoring balance to the specific functioning modes whose malfunctioning causes the chronic pain. Incomplete digested food creates toxins and impurities that are eventually absorbed, travel through the physiology localize in tissue and disrupt their functioning, leading to a chronic pain. This is treated by proper use of spices and cooking oil by favouring digestion-enhancing foods and by reducing digestion-depressing foods.[37]

\section{Yoga}

Yoga have been proved to be a positive effect in pain relief and provides some evidences to support the application of yoga as an alternative therapeutic modality in pain management. Some studies demonstrated that people will achieve better muscle strength and stamina as well as steadiness and flexibility after yoga exercise.[38] Studies have established the role of yoga in decreasing the pain and disability in chronic low back pain, along with improved flexibility within 1 week to 4 months of yogic intervention with no adverse effects. [39]

Mind sound resonance technique (MSRT) is one of the advanced guided yoga relaxation techniques that can be practiced in sitting posture to achieve the goal of positive health, will power, concentration and deep relaxation.[40],[41]. MSRT opens up the secret of traditional chants called Mantra. MSRT generates resonance throughout the body by repetitions of mental sounds, Ahata and Anahata. Ahata sound is one which is heard and Anahata sounds are those which are unheard.Anahatasound is an Inner sound or a mental sound which deep meditators hearinside their heart. Resonance generated by MSRT helps in revitalizing the internal energy in the body. It takes to deeper layer of silence, wardsoff all fears. There is tremendous expansion within, which can bringpowerful healing. MSRT was one of the components of the intensive integrated yoga program that can be used as the intervention for low backpain study.[42]

\section{DISCUSSION}

This article explores the concept of Pain in classical texts of Ayurveda mitigating by modern perspective. The treatment modalities such as Snehan karma, Swedan karma, Agnikarma, Raktamokshanby Jalauka, Lepanchikitsa, Bastikarmaare discussed followed by brief recitation of palliative medicine i.e. Shaman chikitsa. Sensitization of pain and process of inflammation are mediated by G-Protein Coupled Receptors (GPCRs). Ligands (biomolecule) attach to the GPCRs and cause conformation of GPCRs results in transmission of signals to the nucleus, thus, controls the functions of the cell. The DhatukshayajanyaVataprakopaleads to abnormal signal initiation gives rise to defect in GPCRs in turn, leading to over signaling within the cell. This over signaling causes inflammation within the cell. Margaavrodhthat is defect in transmission of signals via GPCRs causes less perception of signals by the cell thereby, disrupting cell functioning leading to accumulation of metabolite toxins within the cell again leading to inflammation.

Ayurvedic formulations such as Angamardan, ShoolPrashamanand VednasthapakMahakashayaare mentioned in CharakSamhita. The AngamardaMahakashayacan be prescribed for Angamarda(body ache) in both Dhatukshaya and Margavrodhjanyavataprakop, ShoolprashamiyaMahakashayhas Ushanproperty, hence, useful abdominal colic; whereas, VednasthapakMahakashayahas Kashaya Rasa and Sheetaviryacan be used effectively in pain management due to traumatic conditions.

Further, medicines like Ajmodadichurna, Shankhvati, Rasonadivati, Agnitundivati, Hingvadichurnaetc. are used in Udarshooland formulations of Guggul, Shallaki, Dashmool, Shuntthi, Haridra, Ashwagandha, Rasna, RaktaChandan, AamVateshwar - Vatachintramani Rasa are used effectively in other painful condition with varied prognosis. 
${ }^{1}$ KaleVrushali , International Journal of Ayurvedic \& Herbal Medicine 9(3) May.-June. 2019 (3546-3552)

This article also throws a light on importance of yoga therapies. Yoga is considered to be an aerobic exercise combined with breathing training and relaxation therapy and it may have positive effects on pain relief, not just in physical but also psychological aspects, so a broaden assessment system for yoga is needed to be established in future studies.

\section{REFERENCES}

1. VallathN.,Perspectives on yoga Inputs in the Management of Chronic pain, Indian J. Palliat Care, 2010, Jan-Apr; 16 (1); 1-7.

2. Eide P.K., Pathophysiological mechanism of central neuropathic pain after spinal cord injury. Spinal Cord. 1998; 36:601 - 12.

3. https://en.wikipedia.org/wiki/International Association for the Study of Pain [Last accessed on 14/02/2018]

4. Charaka, Katidhadhaypurushiyaamshaarir. In: Vaidyamanorama Hindi Commentary, Acharya VidyadharShukla, Prof. RaviDuttTripathi, CarakaSamhitaPurvaardhasharirsthan, 2nd ed. Varanasi : Chaukhamba Sanskrit Pratishthan ; 2007. p.691,1:92.

5. Charaka, Shadvirechanshatashritiyaadhyay. In: Vaidyamanorama Hindi Commentary, Acharya Vidyadhar Shukla, Prof. RaviDuttTripathi, CarakaSamhitaPurvarardha.

6. A. Lazaridou, P. Philbrook, and A.A. Tzika, "Yoga and mindfulness as therapeutic interventions for stroke rehabilitation: a systematic review", Evidence based Complementary and Alternative Medicine, vol. 2013, Article ID 357108, 9 pages, 2013.

7. E. Ernst, M.H. Pittler, B. Wider et al., Oxford Handbook of Complimentary Medicine, Oxford University Press, Oxford, UK, 2008.

8. K.L. Kappmeier and D.M. Ambrosini, Intructing Hatha Yoga, Human Kinetics, Champaign, III USA, 2006.

9. Sutrasthana, 2nd ed. Varanasi :Chaukhamba Sanskrit Pratishthan ; 2007. p. 77, 4:44,45,47.

10. Susruta, Gulmapratishedh.In : Prof. K.R.Srikantha Murthy, SusrutaSamhita uttarardha,2nd ed. Varanasi : ChaukhambaOrientalia ; 2005.p.271,42:81

11. Charaka, Vatvyadhichikitsaadhyay. In : Vaidyamanorama Hindi Commentary, Acharya Vidyadhar Shukla, Prof. RaviDuttTripathi, CarakaSamhitaUttarardha, 2nd ed. Varanasi : Chaukhamba Sanskrit Pratishthan ; 2007. p. 699,28:59.

12. Susruta, Gulmapratishedh.In : Prof. K.R.Srikantha Murthy, SusrutaSamhita uttarardha,2nd ed. Varanasi : ChaukhambaOrientalia ; 2005.p.276-279, 42:117-141.

13. Mahamatishrimadhavkar, Shoolparinaamshoolannadravshoolshoolnidana. In: Shri. Pandit Brahmashankar ShastriBhishakratna, Madhavnidanam. Varanasi :Chaukhamba Sanskrit Sansthan; 2012. p. 180,26:1

14. Yogratnakar, Shoolnidan. In :VaidyaShrilaxmipatishastri, Yogratnakaruttarardha, 8th ed. Varanasi : Chaukhamba Sanskrit Sansthan ; 2004. p.5

15. VriddhaJivaka, Shoolchikitsaadhyay, In :PanditHemraj Sharma, KashyapsamhitaKhilsthana, 1st ed., Varanasi : Chaukhamba Sanskrit Sansthan ; 2010. p.345,18:4

16. https://www.britannica.com/science/thermoreception[Last accessed on 25/01/2018].

17. Charaka, Kalpanasiddhiadhyay. In : Vaidyamanorama Hindi Commentary, Acharya Vidyadhar Shukla, Prof. RaviDuttTripathi, CarakaSamhitaUttarardhasiddhisthanam, 2nd ed. Varanasi : Chaukhamba Sanskrit Pratishthan ; 2007. p. 883,1:40

18. https://www.researchgate.net/publication/282324532_Understanding_The_Mode_Of_Action_Of _Bastikarma_Medicated_Enema [Last accessed on 25/01/2018]. 
${ }^{1}$ KaleVrushali , International Journal of Ayurvedic \& Herbal Medicine 9(3) May.-June. 2019 (3546-3552)

19. Dwivedi and Lakshmanan, 2015 , Agnikarma: A Reference Manual for Ayurvedic Physicians Information Directly Extracted from Approximately 3000 Years Old Literature, Ayurvedic, VRI Press, Vedic Research, Inc. USA, Volume 2, Issue 2, November 2015, Pages 19-28

20. https://www.britannica.com/science/thermoreception[Last accessed on 25/01/2018]

21. Charaka, Kalpanasiddhiadhyay. In : Vaidyamanorama Hindi Commentary, Acharya Vidyadhar Shukla, Prof. RaviDuttTripathi, CharakaSamhita Uttarardhasiddhisthanam, 2nd ed. Varanasi : Chaukhamba Sanskrit Pratishthan ; 2007. p. 883,1:40

22. Amarprakash P. Dwivedi, Case study of Leech Application in Diabetic Foot Ulcer, Int.J.Res.Ayur. Pharm.2012; 3(5): 748-751

23. Charaka, Kalpanasiddhiadhyay. In : Vaidyamanorama Hindi Commentary, Acharya Vidyadhar Shukla, Prof. RaviDuttTripathi, CarakaSamhita Uttarardhasiddhisthanam, 2nd ed. Varanasi : Chaukhamba Sanskrit Pratishthan ; 2007. p. 883,1:40

24. Charaka, Kalpanasiddhiadhyay. In : Vaidyamanorama Hindi Commentary, Acharya Vidyadhar Shukla, Prof. RaviDuttTripathi, CarakaSamhita Uttarardhasiddhisthanam, 2nd ed. Varanasi : Chaukhamba Sanskrit Pratishthan ; 2007. p. 883,1:40

25. https://www.ncbi.nlm.nih.gov/pmc/articles/P MC4263906/ [Last accessed on 25/01/2018]

26. https://www.painscience.com/biblio/hpa-axis-dysfunction-and-chronic-pain-risk.html [Last accessed on $25 / 01 / 2018$ ]

27. Vagbhata, Aayushkamiyaadhyay, In : Prof.K.R.Srikantha Murthy, AshtangHridayamsutrasthanam, 1st ed. Varanasi : Chowkhamba Krishnadas Academy ; 2007.p.10,1:15

28. https://www.ncbi.nlm.nih.gov/pubmed/26590 341 [Last accessed on 25/01/2018]

29. Charaka, Kalpanasiddhiadhyay. In: Vaidyamanorama Hindi Commentary, Acharya Vidyadhar Shukla, Prof. RaviDuttTripathi, CarakaSamhitaUttarardhasiddhisthanam, 2nd ed. Varanasi : Chaukhamba Sanskrit Pratishthan ; 2007. p. 883,1:40

30. https://www.researchgate.net/publication/282 324532_Understanding_The_Mode_Of_Action_Of _Bastikarma_Medicated_Enema [Last accessed on 25/01/2018]

31. https://www.ncbi.nlm.nih.gov/pmc/articles/P MC4263906/ [Last accessed on 25/01/2018]

32. Charaka, Kalpanasiddhiadhyay. In : Vaidyamanorama Hindi Commentary, Acharya Vidyadhar Shukla, Prof.RaviDuttTripathi, CarakaSamhitaUttarardhasiddhisthanam, 2nd ed. Varanasi : Chaukhamba Sanskrit Pratishthan ; 2007. p. 883,1:40

33. https://www.researchgate.net/publication/282 324532 Understanding The Mode Of Action Of Bastikarma Medicated Enema [Last accessed on 25/01/2018]

34. https://www.ncbi.nlm.nih.gov/pmc/articles/PMC4263906/ [Last accessed on 25/01/2018]

35. Vagbhata, Aayushkamiyaadhyay, In : Prof.K.R.Srikantha Murthy, AshtangHridayamsutrasthanam, 1st ed. Varanasi : ChowkhambaKrishnadas Academy ; 2007.p.10,1:15

36. https://www.researchgate.net/publication/282324532.

Understanding_The_Mode_Of_Action_Of_Bastikarma_Medicated_Enema [Last accessed on 25/01/2018]

37. Tick H. Nutrition and pain, PhysMed RehabilClin N Am. 2015 May;26(2):309-20. doi: 10.1016/j.pmr.2014.12.006. Review. PMID: 25952067

38. LaidiKan, Jiaqi Zhang, Yonghong Yang, and Pu Wang, The effect of Yoga on Pain, Mobility and Quality of life in Patients with Knee Osteoarthritis: A systematic Review, "Evidence based Complementary and Alternative Medicine, Vol. 2016, Article ID 6016532, 10 pages.

39. Tekur P., Singphow C., Nagendra H.R., Raghuram N., Effect of short-term intensive yoga program on pain, functional disability and spinal flexibility in chronic low back pain: A randomized control study. J. Alten. Complement. Med. (2008), 14: 637- 644. 
${ }^{1}$ KaleVrushali , International Journal of Ayurvedic \& Herbal Medicine 9(3) May.-June. 2019 (3546-3552)

40. Michaels R.R., Huber M.J., McCann D.S., Evaluation of transcendental meditation as a method of reducing stress. Science (1976), 192, 1242 - 1244.

41. Vempati R.P., Telles S., Yoga based guided relaxation reduces sympathetic activity judged from baseline levels. Psychol. Rep. (2002), 192, 487 - 494.

42. Anuprita S., Complementary effect of MSRT as add on program in patients undergoing Traction and Interferential therapy for chronic low back pain. (2007) Swami Vivekananda Yoga Anusandhana Samsthana, Bangalore, Karnataka. 